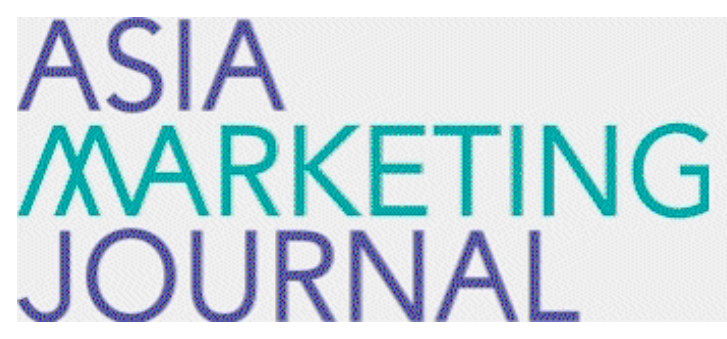

ASIA MARKETING JOURNAL

Volume 12 | Issue 1

Article 4

4-30-2010

\title{
글로벌 기업 도약을 위한 롯데쇼핑의 마케팅전략
}

Jin Yong Lee

Chung Koo Kim

Young Hyuck Joo

Follow this and additional works at: https://amj.kma.re.kr/journal

Part of the Marketing Commons

\section{Recommended Citation}

Lee, Jin Yong; Kim, Chung Koo; and Joo, Young Hyuck (2010) "글로벌 기업 도약을 위한 롣데쇼핑의 마케팅 전략," Asia Marketing Journal: Vol. 12 : Iss. 1 , Article 4.

Available at: https://doi.org/10.53728/2765-6500.1252

This Article is brought to you for free and open access by Asia Marketing Journal. It has been accepted for inclusion in Asia Marketing Journal by an authorized editor of Asia Marketing Journal. 


\title{
글로벌 기업 도약을 위한 롯데쇼핑의 마케팅전략*
}

\section{Lotte Shopping's Marketing Strategy for Achieving the Goal of Becoming a Global Leader*}

\author{
이 진 용(Lee, Jinyong)** \\ 김 정 구(Kim, Chung $\mathrm{Koo})^{* * * *}$ \\ 주 영 혁(Joo, Young-Hyuck)****
}

롯데쇼핑은 롯데백화점에서 출발하였다. 롯데쇼핑주식회사를 출범하면서 1979년 국내 최대 백화점 을 개점하였고, 지속적인 점포 개설 및 타 기업 인수합병을 통하여 규모를 확대하였다. 현재 백화점, 마트, 영화관, 쇼핑몰, 슈퍼마켓을 비롯하여 롯데홈쇼핑, 롯데닷컴 등 TV 홈쇼핑, 온라인 쇼핑 등 다 양한 오프라인 및 온라인 소매업 분야에서 사업을 운영하고 있다.

롯데쇼핑이 소속되어 있는 롯데그룹은 글로벌그룹 도약의 목표를 가지고 있다. 2009년 2018 아시아 $\mathrm{TOP} 10$ 글로벌 그룹이라는 비전을 선포하고 이를 실천하기 위하여 노력하고 있다. 롯데쇼핑은 글로 벌 그룹 도약이라는 비전 달성을 위한 그룹 전체의 성장전략을 실천하기 위하여 적극적인 기업 인수 합병 및 다양한 마케팅전략을 수립하여 실행에 옮기고 있다.

다음에서는 롯데쇼핑 현황을 간략하게 살펴본 후에 롯데쇼핑의 핵심적인 마케팅 전략인 “복합화 및 다채널화”와 “해외시장 진출 전략”, 그리고 이를 뒷받침하기 위한 기본적 인프라 구축과 인재양성 을 위한 “교육시스템”에 대하여 분석하기로 한다.

핵심개념: 롯데쇼핑, 롯데백화점, 롯데마트, 복합화, 다채널화, 해외시장진출전략, 교육시스템

\section{I. 롯데쇼핑 현황}

롯데쇼핑은 2009년에 11조 5353억원 매출 및
7164 원의 당기순이익을 기록하여 10 조 16 억원 매출, 5680원 당기순이익을 달성한 신세계 및 8387억원 매출, 2390억원 당기순이익을 올린 현 대백화점에 비하여 좋은 성과를 보였다(http:

\footnotetext{
* 자료 제공에 협조하여 주신 롯데쇼핑 담당자, 박대훈 팀장, 백인수 소장께 감사의 말씀을 드립니다.

** 중앙대학교 경영대학 교수(leejy@cau.ac.kr)

**** 성균관대학교 경영전문대학원 교수(kimkim@skku.edu)

***** 한성대학교 경영대학 부교수(mrjoo@ hansung.ac.kr)
} 
//dart.fss.or.kr, 금융감독원 전자공시시스템). 롯 데쇼핑의 주력 사업분야는 백화점과 할인점으 로 각각 매출의 $51.2 \%, 37.5 \%$ 로 5조 9045 억원, 4 조 3228 억원이다. 백화점 매출과 영업이익은 1 조원에 미치지 못하는 신세계와 현대백화점을 크게 앞지르고 있지만 할인점은 업계 1 위인 신 세계 이마트의 매출 7조 9464억원 및 영업이익 6897억원과 꽤 차이가 있는 상태이다(자세한 내 용은 금융감독원 전자공시 시스템을 참조하시오).

롯데쇼핑이 현재와 같이 성장한 것에는 지속 적인 점포개발 및 적극적인 기업 인수 합병 전 략이 주효하였기 때문이다. 1979년 백화점 1호 점 개점, 이후 잠실점 개점 등에서 알 수 있듯 이 경쟁 점포가 엄두조차 내기 어려운 넓은 매 장 및 차별화된 점포 운영을 통하여 시장점유 율을 높였으며 여러 기업들을 인수하기도 하였 다. 2002년에서 미도파를 인수하여 미도파 노원 점 등 8개 점포를 추가하였고, 2004년에 한화수 퍼 25개점을 매입하기도 하였다. 2010년에는 GS 리테일의 백화점 3 개점 및 대형마트 14 개 를 인수하여 국내시장에서 백화점 29개점, 대형 마트 84 개점으로 증가한다. 특히 백화점 분야의 경쟁기업인 신세계(백화점 8개 점포), 현대백화 점(백화점 11 개 점포)을 크게 능가하게 되었다.

롯데쇼핑은 해외 점포망 확충에도 상당한 노 력을 기울여 101 개의 롯데마트와 2 개의 롯데백 화점을 중국 등 해외시장에서 운영하고 있다. 해외에서도 2007년 중국 마크로, 2008년 인도네 시아 마크로, 2009년 중국 대형마트 타임즈 등 을 인수하여 해외 점포망 확대에 많은 투자를 하고 있다.

롯데쇼핑은 복합점포 및 다채널화, 그리고 해 외시장에 적극적인 진출 등을 통한 글로벌 기
업 도약이라는 비전을 실현하기 위하여 내부적 으로 조직문화 확산, 환경 및 사회공헌 경영 등을 강조하고 있다. 신동빈부회장은 2009년에 “2018 아시아 TOP 10 글로벌 그룹”이라는 비 전을 선포하고 이를 달성하기 위하여 구성원들 이 적극적으로 동참할 것을 부탁하였다. 다양한 방법으로 성장한 롯데쇼핑은 전세계 상위 유통 기업 중에서 다각화된 유통기업 9위, 성장률 24 위 등에 기록된 바 있다(Deloitte 2010).

롯데쇼핑 구성원들은 비전 달성을 위하여 초 창기 경영이념을 항상 잊지 않기 위해 노력한 다. 롯데백화점 이철우 사장은 회사에서 일하는 사람이라면 누구나 조직의 일부라고 생각하여 사가를 만들어 부르게 하고 경영이념을 외우게 했다. 롯데쇼핑 구성원은 무슨 일을 하든지, 경 영이념에 담긴 핵심 가치를 실현할 수 있도록 동기를 부여한 것이다. "Always with you”라는 경영이념은 “언제나 고객과 함께”라는 뜻으로, 늘 한결같이 진실하고 정직한 마음에서 우러나 오는 “고객중심 경영”을 표현했다(이철우 2009). 롯데쇼핑은 2004년 업계 최초로 환경가치 경 영을 선포했다. 환경문제에 대한 중요성이 높아 지면서 사람과 사회에 기여하는 친환경 경영으 로 거듭나겠다는 목표를 대외적으로 선포한 것 이다(http://www.lotteshopping.com/lotte/ about/ceo/ceo.jsp). 환경가치 경영은 내부조직, 매장, 사회·환경의 3 대 영역에서 수행되었고 이미 보유하고 있는 역량을 최대한 활용하는 방식으로 진행하였다. 소비자와 함께 수행하는 친환경프로그램을 운영하였다. 고객이 상품권을 구입하면 환경상품권제도를 통해서 일정금액을 적립해서 환경재단에 기부하는 방식으로 이루 어져 누구나 환경 보호에 쉽게 동참할 수 있는 
프로그램을 운영하기도 하였다(롯데쇼핑 2009).

2005년에는 업계 최초로 지속가능성 보고서를 발간했다. 환경의 중요성을 재고할 수 있도록 경제, 사회, 환경적 성과와 비전을 제시하는 책 자이다. 이런 노력의 결과로 롯데 백화점이 2009년 2월 28일 신설된 다우존스 지속가능성 지수(DJSI: Dow Jones Sustainability Indexes) 에 국내 유통업계 최초로 등재되었다. DJSI에 등록된 기업들은 아시아, 태평양의 시가총액 상 위 기업 중에서 지속가능 경영을 우수하게 수 행하고 있는 기업이다. 롯데 쇼핑은 환경뿐만 아니라 다양한 내용으로 사회공헌 활동을 선도 적으로 수행해왔다. 출산장려, 협력회사와 상생 경영 등이 중요한 활동 내용이다.

\section{II. 복합화 및 다채널화}

'우리 회사의 주인은 고객이십니다.' 이것은 롯데쇼핑의 사시(社是)이다. 소득수준, 소비성 향, 인구구성, 주거환경에 걸친 사회경제적 변 화에 따라 고객의 옥구가 더욱 복잡-다양해지 고 있음에도 롯데백화점이 1979년 개점부터 30 년 넘게 1 등 백화점을 유지할 수 있었던 것은 고객 중심 마인드가 있었기 때문이다. 롯데백화 점은 단순한 상품판매만을 하는 백화점은 고객 들을 만족시킬 수 없다고 판단하고 시대별로 고객의 욕구를 충족시켜 줄 수 있는 방안을 지 속적으로 모색하여왔다. 이러한 롯데백화점의 정신은 첫째, 단순한 상품판매에서 그치지 않고 오락과 편의시설 기능이 부가된 쇼핑센터 개념 의 쇼핑공간을 제공하기 위한 복합화 및 세분
시장별 욕구충족을 위한 전문화, 둘째, 다양한 유형의 유통채널을 통하여 고객의 다양한 옥구 를 충족 및 편리성을 충족시키기 위한 다채널 화로 요약될 수 있다. 이러한 두 가지 차원에서 의 롯데백화점의 노력의 핵심은 고객중심적인 마인드에서 비롯되고 있다고 할 수 있다. 〈그림 $1>$ 은 롯데백화점의 복합화와 다채널화 전략의 구체적인 내용을 제시하고 있다.

〈그림 1〉 롯데백화점의 복합화 및 다채널화 전략방향

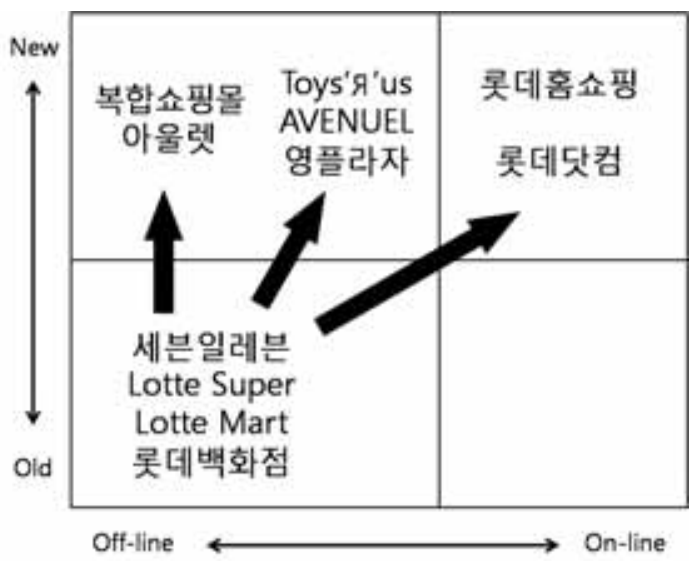

\section{1 복합화 및 전문화}

복합화는 단순한 매장 위주에서 레저, 엔터테 인먼트, 극장 등과 연계시킨 복합적인 시설을 지향하여 다양한 고객의 욕구를 충족시켜 한 장소에서 이를 향유케 하는 것이다. 경쟁격화로 인하여 규모면에서 제일의 점포로서의 위상 및 복합화가 조류가 되고 있는데, 단순한 상품판매 에 오락(entertainment), 편의시설(amenity) 기 능이 부가된 쇼핑센터 개념의 복합공간으로 고 객을 흡인할 수 있어야 한다. 전문화의 경우 기 
업과 소비자 측면의 2 가지 관점에서 접근할 수 있다. 기업측면의 전문화란 소비자의 구매가 점 차 고급화·전문화되는 방향에 맞추어 상품구 색을 구성하는 것을 의미한다. 즉, 모든 종류의 상품구색을 갖추지 않고 고급제품 그리고 특정 상품계열을 집중적으로 진열하는 형태의 전문 화를 의미한다. 반면, 고객측면의 전문화란 주 먹구구식 고객관리 관행에서 벗어나 명확한 표 적고객의 설정 및 기존 고객의 철저한 과학적 관리가 요구되는 차원에서의 전문화를 의미한 다(김병도, 주영혁 2006). 이러한 측면에서 롯 데백화점의 복합화 및 전문화의 내용을 소개하 면 아래와 같다.

\subsection{1 쇼핑과 엔터테인먼트와의 복합화}

롯데백화점은 개점 초기부터 제품판매를 위한 쇼핑공간의 의미를 뛰어넘어 휴식을 취하고 즐 길 수 있는 문화공간을 지향하였다. 초기의 문 화공간으로서의 의미는 대형 주차장, 유아 휴게 실, 롯데화랑 등 고객서비스 제공을 통한 편리 성 제고의 의미를 가지고 있었다. 그러나 진정 한 의미의 최초의 복합쇼핑몰은 1988년 문을 연 잠실 롯데월드라고 할 수 있다. 이후 복합쇼 핑몰의 등장이 예견되었으나 외환위기를 겪으 면서 그 시기가 늦어졌다.

이후 롯데백화점은 영화관과 쇼핑, 외식 등이 한 곳에서 이루어지는 복합문화공간으로서의 백 화점을 만들기 위해 1999년에 멀티플렉스 체인 인 롯데시네마를 개장하였다. 이후 1999년 10월 일산에 문을 연 롯데백화점 10호점은 '생활 속 패션 1 번지 백화점'의 콘셉트 아래 지역밀착형 고급백화점과 알뜰쇼핑 공간이라는 이미지를
구축하자 하였다. 특히 일산점은 고객의 복잡하 고 다양한 요구에 부응하고자 쇼핑과 엔터테인 먼트 트렌드에 맞춰 시네마가 복합된 최초의 백화점이라는 데 의의가 있다.

멀티플렉스 영화관과 영화배급 사업을 전개하 는 롯데시네마는 진입 초기에 선발업체들과의 차별화를 꾀하기 위해 출점 예정인 모든 백화 점에 멀티플렉스를 설치, 운영하기로 하고 '백 화점+멀티플렉스'를 기본 전략으로 확정했다. 이 에 따라 가장 먼저 1999년 10월 롯데백화점 일 산점에 6 개관 규모의 멀티플렉스를 개관, 첫해 에 입장객 14 만 4000 명, 매출액 8 억 원을 올리 며 영화관사업의 핵으로 떠올랐다. $\mathrm{CGV}$ 와 메 가박스 등 이미 경쟁사들이 멀티플렉스시장을 선점하고 있었음에도 불구하고 이처럼 큰 성공 을 거둘 수 있었던 요인은 '백화점 속 영화관' 이라는 콘셉트로 하나의 공간에서 영화 관람과 쇼핑, 문화교실, 외식, 게임등 원스톱 엔터테인 먼트를 실현해 냈기 때문이었다.

현재 전체 멀티플렉스 중 14 개가 롯데 백화점 이나 롯데마트와 함께 위치하고 있어 고객을 양 방향으로 유도하는 등 뛰어난 시너지 효과를 발 휘하고 있다. 특히 프리미엄 상영관인 샤롯데관, 전문 공연시설을 갖춘 라이브 시티관, 예술영화 전용관 아르떼 등 차별화된 부대시설과 더불어 베이비 시트 대여, 무료우산 대여, 수수료 없는 인터넷 예매, 좌석 선택제 등 고객 맞춤형 서비 스로 고객들의 지속적인 사랑을 받고 있다.

2009년 4월 현재 롯데백화점은 잠실 제2롯데 월드, 부산 광복동 롯데타운, 수원 $\mathrm{KCC}$, 김포 스카이파크 등의 복합쇼핑몰 건립을 준비하고 있다. 롯데쇼핑 쇼핑몰 사업부는 2005년 미래성 장동력으로 교외형 복합쇼핑몰을 개척하기 위 
해 설립되었다. 김포 스카이파크의 경우 2006년 6 월 한국공항공사로부터 스카이파크 쇼핑몰 개 발 사업권을 획득, 새로운 도약의 기반을 마련 하였다. 김포국제공항 내에 스카이파크 쇼핑몰 이 완공되면 백화점, 할인점, 멀티플렉스, 카테 고리킬러, 전문점 등 롯데의 모든 유통매장과 엔터테인먼트 점포가 집결된 미래형 복합쇼핑 몰이 탄생할 것이다. 스카이파크 쇼핑몰은 롯데 월드처럼 롯데의 모든 유통과 엔터테인먼트 매 장을 한 곳에서 만날 수 있는 대규모 복합쇼핑 몰로서 2012년에 쇼핑몰이 개점되면 고객들에 게 보다 특별한 쇼핑과 레저, 휴식의 경험을 제 공할 수 있을 것으로 예상된다.

\subsection{2 복합화와 전문화의 쇼핑 커뮤니티로서 '롯데타운'}

롯데백화점은 세분시장별 고객의 욕구를 반영 하기 위하여 명품 전문점, 패션 전문점 등 다각 적인 전략을 전개하여 경기 변동과 고객 니즈 변화에 선행적으로 대응하며 프리미엄 시장과 젊은 고객 대상 시장을 꾸준히 확대해 나갔다. 이러한 세분시장별 고객의 옥구를 충족시키는 업태들의 경우 집객효과를 극대화하기 위하여 타운의 형태로 구축하여 새로운 유형의 복합화 를 시도하였다.

대표적인 형태는 서울 명동의 '롯데타운'으로서 이는 2003년 11월 영플라자를 시작으로 2005년 3 월 에비뉴엘과 8 월에 본관 리뉴얼을 마치기까 지 2년여 동안의 공사를 통해 구축되었으며, 고 객들이 자극을 받고 몸소 체험할 수 있는 공간 으로서의 백화점을 원하는 고객들의 니즈를 충 족시키기 위해 탄생하였다. VIP 고객을 위한 프
리미엄 브랜드를 제공하는 명품관인 에비뉴엘 과 젊은이들을 위한 영패션 전문점인 영플라자 를 통해 명품과 영패션이라는 카테고리를 강화 하였다. 롯데타운은 또한 다양한 유형의 복합화 요소로서 롯데호텔, 면세점, 시네마 등의 엔터 테인먼트 요소까지 가미한 종합쇼핑 커뮤니티 로 새롭게 태어났다.

영플라자는 패션에 관심이 많은 젊은 층을 대 상으로 한 패션 전문점으로 경기 변동에 큰 영 향을 받지 않는 10,20 대의 젊은 고객들이 주요 고객으로 하여 점포 외관으로부터 디자인, 층별 구성과 상품군 등 모든 면에서 젊은 층에게 맞 춤화시켰다. 또한 에비뉴엘은 경기 흐름에 상관 없이 명품에 대한 수요가 꾸준히 증가하고 있 는 점에 착안하여 명품 쇼핑 공간, 호텔 같은 문화공간, 차별화된 서비스를 갖춘 품격 있는 명품관으로 탄생했다. 영플라자와 에비뉴엘은 롯 데백화점 본점, 롯데호텔 등과 함께 서울 도심 에 유통, 레스토랑, 엔터테인먼트, 레저 등이 시 너지를 발휘하는 '롯데타운’을 형성하였다.

\subsection{3 데스티네이션 유통으로서 프리미엄 아울렛}

롯데백화점은 고객의 라이프스타일의 변화 및 새로운 유형의 쇼핑형태에 대한 고객의 옥 구를 충족시키기 위하여 2008년에 데스티네이 션(destination) 유통에 진출하였다. 데스티네이 션 유통이란 교외의 아울렛 몰(outlet mall)처 럼 목적형 쇼핑을 추구하는 전문 유통점을 의 미하는 것으로, 소득수준이 높고 주 5일제가 정 착된 미국과 유럽 등에서 널리 확산되고 있는 유통방식이다. 롯데쇼핑은 데스티네이션 유통의 
하나의 형태로서 아울렛 몰을 본격적으로 도입, 운영함으로써 소득수준의 향상과 함께 주 5 일 제가 정착됨으로써 좀 더 다양해진 고객들의 욕 구를 충족시키고자 노력하였다.

2008년 10월에 개점한 광주월드컵점은 롯데마 트와 함께 위치한 도심형 아울렛 몰로, 190 개에 달하는 국내 최고의 패션브랜드가 들어서 고객 의 다양한 니즈에 대응하고 있으며, 개점 후 3 개월 동안 예상을 훨씬 넘어선 우수한 판매 실 적과 매달 평균 200,000 여 명에 달하는 고객이 방문하는 성과를 거두었다. 이어 12 월에 개점한 김해 프리미엄 아울렛 몰은 세련된 분위기, 넓 고 쾌적한 공간, 그리고 다양한 식당과 편의시 설을 갖춘 교외형 아울렛 몰로 버버리, 아이그 너, 듀퐁, 라우렐 등 약 20 개에 달하는 글로벌 명품 브랜드와 110 개가 넘는 국내외 우수 브랜 드들이 입점하였다. 2009년 3월 현재 개점 후 3 개월 동안 월 평균 300,000 여 명 이상의 고객이 방문하는 등 괄목할 만한 실적을 기록하였다. 김해관광유통단지 내에 위치하여 입지 여건이 탁 월할 뿐만 아니라 지역의 명소로 급부상하고 있 어 앞으로 성장세가 더욱 커질 것으로 예상된 다. 아울렛 몰 사업의 성공적인 진출을 통해 롯
데 백화점은 백화점에서 명품 전문점, 패션 전 문점, 아울렛 몰을 아우르는 종합 유통채널을 확 보, 유통산업에서의 리더십을 더욱 강화하였다.

\section{2 다채널화}

이는 종합화로서 설명되기도 하는데 백화점이 다양한 소매업태 또는 그와 관련된 제조업으로 진출하는 것을 의미한다고 할 수 있다(김병도, 주영혁 2006). 2006년 8월 롯데쇼핑은 TV홈쇼 핑업체인 (주)우리홈쇼핑을 인수함으로써 $\mathrm{TV}$ 홈쇼핑 시장에 진출하였다. 이를 통해 백화점과 할인점, 전문점, 쇼핑몰, 편의점, 슈퍼마켓 등 오프라인과 인터넷쇼핑몰에 $\mathrm{TV}$ 홈쇼핑 등 온라 인을 추가하여 전 유통채널을 아우르는 기반을 마련하였다. 롯데쇼핑의 이러한 다채널화는 개 별 소비자가 요구하는 유통서비스가 다양해짐 에 따라 이러한 옥구에 적합한 유통형태를 운 영하여 고객들을 만족시키고자 함이라 할 수 있으며, 비관련 보다는 고객 중심적인 관련 다 채널화에 초점을 맞추고 있다는 특징을 가지고 있다. 주요 유통기업의 다채널화의 내용을 표로 정리하면 아래와 같다.

〈표 1〉 주요 유통업체의 다채널화 현황

\begin{tabular}{|c|c|c|c|c|c|}
\hline 구분 & 롯데 & 신세계 & 현대백화점 & 한화유통 & GS리테일 \\
\hline 대형마트 & 0 & $\star$ & & & 0 \\
\hline 백화점 & $\star$ & O & $\star$ & $\star$ & 0 \\
\hline 슈퍼마켓 & 0 & & & & $\star$ \\
\hline 편의점 & 0 & & & & $\star$ \\
\hline 홈쇼핑 & 0 & & ○ & & 0 \\
\hline 인터넷 & 0 & 0 & ○ & $\bigcirc$ & 0 \\
\hline
\end{tabular}

주 : `-주력, $\mathrm{O}$-진출

〈자료원: 2009년 국내 소매시장 전망〉 
최근 롯데쇼핑은 2010년 상반기 점포수 기준 편의점 업체 4 위 기업인 바이더웨이를 인수하 여 2위인 GS편의점과의 격차를 줄이게 되었으 며, 또한 GS리테일의 백화점과 대형마트를 인 수함으로써 백화점의 시장지위를 제고함과 더 불어 대형마트에서 이마트와 홈플러스와의 3 파 전 양상을 전개하기 위한 기초를 마련하였다. 그러나 롯데쇼핑의 경우 다채널화를 통하여 고 객의 쇼핑편리성을 제고하기 위한 노력을 지속 적으로 수행함으로써 고객지향적인 다채널화를 전개하고 있다. 예를 들면, 백화점의 멤버쉽 고 객을 대상으로 인터넷과 홈쇼핑을 통한 구매 시 편리성을 제고하기 위한 노력 등이 그 예라 고 할 수 있다. 유통업체의 경우 소비자가 요구 하는 유통서비스가 다양해지고 있어 이에 적합 한 유통채널을 운영하는 것이 유통업체에는 하 나의 시장기회가 되며 다양한 업태를 운영함으 로써 공동자원(예를 들면, 고객 혹은 기술 등) 에 의한 시너지 효과를 거두는 기회가 된다고 할 수 있다.

\subsection{1 오프라인에서의 다채널화}

롯데백화점은 백화점만으로는 다양해진 고객 의 욕구를 모두 충족시킬 수 없음을 인식하였 다. 이에 따라 할인점, 지역형 슈퍼마켓 및 편 의점을 운영하여 다양화된 고객의 욕구를 충족 시키며 고객들이 보다 편리하게 이용할 수 있 는 방안을 모색하였다 고객에게 좀 더 싸고 좋 은 제품을 공급하기위해 1998년에 할인점인 '롯 데마트'를 개설하였으며, 할인점이나 백화점이 미치지 않는 소상권을 주타겟으로 하고 있는 지역형 슈퍼마켓인 '롯데슈퍼’의 경우 2001년 1
호점을 오픈한 이후 2009년 현재 110개점을 운 영 중이다. 또한 1994년 소득수준 향상과 핵가 족화 확대, 심야활동 인구증가 등 사회적 변화 에 따라 편의점 '세븐일레븐'을 적극적으로 추진 한 이후 2009년 2월 말 기준 2002개의 편의점 을 운영 중이다. 이로써 롯데쇼핑은 백화점, 할 인마트, 지역형 슈퍼마켓, 편의점으로 이어지는 오프라인 채널을 보유함으로써 고객의 상황과 필요에 따라 자신이 원하는 쇼핑방법을 다양하 게 선택할 수 있도록 편의를 제공하고 있다.

(1) 비싼 제품을 더 싸게 '롯데마트'

1990년대 중반 유통시장이 전면 개방되면서 가전제품 등을 취급하는 전자상가는 물론 편의 점, 다양한 형태의 할인점 등이 '가격파괴'를 내 걸고 양산되기 시작했다. 롯데는 좀 더 싸고 좋 은 제품을 구입하고자 하는 고객들의 욕구를 충 족시키기 위해 할인점 사업 진출을 모색, 1995 년대 신업태 추진팀이 발족하면서 할인점 사업 이 본격화되었다. 이후 3 년여의 준비 기간을 거 쳐 1998년 4월 할인점 1호점인 강변점이 탄생 되었다. 롯데마트의 초기 이름은 끌어당기는 성 질을 지닌 자석을 의미하는 '마그넷(Magnet)' 이었다. 마그넷(2002년 롯데마트로 상호변경)은 백화점 수준의 첨단 시설과 교통이 편리한 입 지, 그리고 단지 싼 상품을 싸게 파는 것이 아 니라 비싼 제품을 더 싸게 파는 전략으로 타 할인점과 차별화를 꾀했다.

롯데마트의 가장 큰 장점은 식료품과 의류에 서부터 가전제품에 이르기까지 다양한 고품질 의 제품을 경쟁력 있는 저렴한 가격에 제공한 다는 것이다. 고객들이 할인점을 찾는 가장 큰 이유인 좋은 제품을 싸게 구입하고자 하는 욕 
구를 정확하게 파악한 것이다. 또한 다채널의 시너지를 제고하기 위한 방법으로써 온라인 쇼 핑몰인 LotteMart.com을 통한 무료 배달 서비 스도 고객들에게 큰 호응을 얻고 있으며, 각 점 포들의 상품 구성과 점포 배치는 표준화하면서 점포별로 해당 지역 고객들의 특성과 취향에 맞는 상품구색과 차별화된 서비스를 제공하는 것 또한 롯데마트의 강점이라고 할 수 있다.

롯데마트는 10년 동안 지속적으로 성장을 거 듭하며 최근 2010년 2월에는 GS마트를 인수하 였다. GS마트 인수로 롯데마트는 총 점포 수 84개(롯데 70개, GS마트 14개)가 되었으며 올 해 국내 신규 점포를 10 개 이상 열어 연말까지 100 개가량의 점포망을 구축해 1,2 위 업체인 이 마트(점포 수 127 개), 홈플러스(115개)를 바짝 쫓겠다는 전략을 세웠다. 롯데마트는 후발업체 임에도 불구하고 할인점 업계 3 위에 만족하지 못 하고 정상을 향한 기반을 다지고 있는 중이다.

(2) 지역밀착형 슈퍼마켓, '롯데슈퍼'

롯데백화점은 $\mathrm{IMF}$ 이후 대형할인점의 사업영 역이 급속히 확대되는 속에서도 백화점이나 할 인점이 미치지 않는 상권에서 고객에게 보다 높은 수준의 쇼핑 편의성을 제공하고자 고심하 였다. 이에 2000년 4월 슈퍼사업본부의 전신인 레몬사업본부를 출범시켰다. 이를 통하여 출시 된 롯데슈퍼 1호점인 전농점은 2001년 5월 지 역밀착형 슈퍼마켓(SSM)의 콘셉트로 중 - 대형 규모로 기존 슈퍼마켓과 할인점의 틈새시장을 공략하겠다는 차별화 전략으로 슈퍼마켓시장에 진출했다.

취급상품은 신선식품을 비롯해 가공식품, 즉 석 조리식품 등 식품 비중을 $80 \%$ 까지 구성하
기로 했다. 특히 맞벌이 부부나 독신자 고객들 의 증가 추세를 파악하고 고객에게 보다 적합 한 서비스 방법을 고심한 끝에 각 매장 내에 조리장과 가공시설 등을 갖춰 현장에서 바로 음식을 가공 조리하여 판매하는 즉석 조리방식 을 도입했다. 그 결과 개점 두 달 만에 일평균 4000만 원(평일 기준)대 매출을 올리며 일급 슈 퍼마켓 점포로 정착했다.

롯데슈퍼의 장점은 가까운 입지, 풍부한 상품 구색, 다채로운 신선식품, 합리적인 가격, 편리 한 배달 서비스 등 고객에게 다양한 혜택을 제 공한다는데 있다. 전국의 각 동네마다 현대적인 원스톱 쇼핑 편의성을 제공한다는 목표아래 롯 데슈퍼는 원스톱 쇼핑의 편리함을 고객에게 제 공하였다. 또한, 전략적 합병과 확장을 통해 2008년 전국에 31 개 점포를 새로 개점하여 총 110 개의 점포를 확보함으로써 점포수에서 슈퍼 마켓 업계 1 위에 올랐다.

\subsection{2 온라인을 통한 다채널화}

인터넷 환경에서의 온라인 유통과 오프라인 유통이 결합되는 클릭 앤드 모르타르(Click and Mortar: 인터넷에서의 비즈니스와 실물 세계에 서의 비즈니스를 병행하는 방식)는 오프라인이 든 온라인이든 하나의 유통채널만을 보유하고 있는 유통업체에 비하여 우세하다고 할 수 있 다. 왜냐하면 고객들이 인터넷을 이용하게 됨에 따라 시장에서 고객의 구매행동패턴이 변하고 있기 때문이다. 롯데쇼핑의 경우 기존에 보유하 고 있던 다양한 채널에 인터넷과 홈쇼핑이 추 가되면서 누리게 될 규모의 경제성과 범위의 경제성은 롯데의 경쟁력으로 작용하게 된다. 온 
라인과 오프라인을 통합하여 조달능력, 배송능 력, 제품구색 능력, 고객에 대한 통찰력 등의 시너지 효과를 통해 유통업체의 경쟁우위를 지 속적으로 유지하기 위하여 노력하고 있다.

(1) 유통업체 최초의 가상쇼핑 '롯데닷컴'

국내 인터넷 쇼핑 시장은 2001년 이후 연평균 $29.5 \%$ 씩 판매액이 증가하여 2006년에는 슈퍼마 켓을 제치고 대형마트, 백화점에 이어 3대 유통 채널로 성장하였다. 전체 소매유통에서 인터넷 쇼핑시장이 차지하는 비중도 꾸준히 증가하여 2006 년 기준 $7.4 \%$ 를 기록하였다. 이는 미국의 $2.8 \%$, 일본의 $2.9 \%$ 를 크게 상회한 수치라고 할 수 있다. 인터넷을 매개로 한 $\mathrm{e}$-비즈니스의 파 급효과 및 그 위력을 일찌감치 간파한 롯데쇼 핑은 다른 업체보다 한 발 앞서 이를 준비하기 시작했고 1996년 3월에는 홍보용 홈페이지를 개설했다. 홈페이지에는 백화점 소개, 점포 별 안내, 쇼핑 및 이벤트 정보, 뉴스, 고객의 소리 접수 등을 게재했다. 이후 리뉴얼 작업을 통해 문화센터 소개, 고객서비스 소개 등을 보완해 나갔다. 그 해 6 월에 유통업계 최초로 가상쇼핑 을 통한 상품의 주문과 배달이 가능한 인터넷 백화점(http://www.lotte.com)을 개설함으로써 온라인 쇼핑시대의 개막을 알렸다.

롯데인터넷백화점을 오픈한 후 롯데백화점, 종 로서적, 뮤직랜드 등 국내의 대표적인 오프라인 기업들을 하나로 묶은 온라인 쇼핑몰 '헬로서 울'을 운영하면서 국내 전자상거래 산업을 주도 적으로 이끌었다. 롯데 인터넷백화점은 백화점 본 매장과 동일하게 운영됐으며, 각종 세일이나 판촉행사, 롯데카드 이용 시 누적되는 포인트 마일리지 등 할인혜택도 동일하게 진행시켰다.
또한 회원들에게 각종 회원행사를 통해 사은품 제공이나, 경품, 인터넷 경매, 한정판매 등을 실 시하는 등 혜택을 부여하거나 가격 편익을 제 공했다. 상품구성은 일반 인터넷 쇼핑몰에서 접 할 수 없는 백화점 매장의 고급 브랜드를 비롯 하여 약 1 만여 종에 이르렀으며, 꽃 배달, 이사 서비스 등 롯데 인터넷백화점만의 서비스 상품 을 개발하여 제공했다. 결제 수단으로 롯데카드 는 물론 국내에서 사용되는 모든 신용카드를 사용할 수 있으며 온라인 입금 및 국내 최초로 I-Cash결제를 실시했다. 또 1999년 10월부터 포 인트제를 도입해 상품구매 시 $1 \%$ 의 포인트 금 액을 적립하여 이 포인트로 상품을 구매할 수 있도록 했다.

이후 2002년 2월 롯데 인터넷백화점은 인터넷 쇼핑 비즈니스를 확대·강화하고자 전문회사인 (주)롯데닷컴(www.lotte.com) 별도법인으로 독 립, 롯데쇼핑의 자회사로 거듭났다. 2007년 말 기준 회원 수는 1076 만 명에 이르고 매출액은 3826억 원(2007년)에 달했다. 1996년 대한민국 최초의 온라인 종합쇼핑몰을 출범시킨 이래 10 여 년 동안 지속적인 혁신을 이루면서 롯데의 풍부한 실물 유통망과 전자상거래 노하우를 결 합, 차별화된 인터넷 쇼핑문화를 창조해 나가고 있다. 롯데 백화점과의 공조 강화, 보다 효율적 인 소비자 중심의 프로세스 구성, 패션부문 영 업확대 등을 통해 수익구조 개선을 통해 인터 넷 종합쇼핑몰 뿐 아니라 롯데인터넷 면세점, 롯데타운, 롯데쇼핑닷컴, 롯데멤버스서비스 사 이트를 운영하며 온라인 유통 사업자로 두각을 나타내고 있다. 
(2) 고객의 높은 이익을 위한 '롯데홈쇼핑' 롯데홈쇼핑은 2007년 TV홈쇼핑 채널인 우리 홈쇼핑을 인수한 후, $\mathrm{TV}$ 홈쇼핑과 인터넷 쇼핑 '롯데 아이몰'을 중심으로 본격적인 홈쇼핑 사 업을 전개해 왔다. 롯데백화점이 홈쇼핑 사업에 진출한 이유는 제조업체와 소비자를 직접 연결 함으로써 오프라인 유통업체보다 고객에게 높 은 이익을 제공해줄 뿐만 아니라 급변하는 시 장상황에서 소비자의 즉각적인 반응을 관찰할 수 있기 때문이다. 롯데백화점은 오프라인 유통 채널과 온라인채널을 통합해 나감으로써 보다 많은 시너지 효과를 창출해 내고 있으며, 롯데 쇼핑의 1 천만 고객데이터와 우리홈쇼핑의 9 백 만 고객데이터, 롯데쇼핑의 구매 노하우 등을 서로 공유함으로써 새로운 사업 기회를 창조하 는 것은 물론 롯데 계열사들과의 공동 마케팅 을 통해 고객 기반도 더욱 확장시켜 나가고 있 다. 또한 롯데홈쇼핑은 업계 최초로 모바일 쇼 핑 '롯데 $\mathrm{M}$ 몰'과 디지털 케이블 TV를 활용한 '롯 데 T몰'을 운영하며 온라인 유통산업의 발전에 도 기여하고 있다.

\section{III. 롯데쇼핑의 해외진출전략}

\section{1 해외시장 진출배경 및 시장 선정}

\subsection{1 진출배경}

롯데쇼핑의 해외 진출은 백화점과 마트 부문 에서 이루어지고 있다. 2010년 3월말을 기준으 로, 백화점은 러시아와 중국에 각 1 개씩의 점포
를 운영하고 있고, 마트의 경우 중국에 81개, 베트남 2 개, 인도네시아 19 개로 총 101 개의 점 포를 해외에서 운영하고 있다. 백화점과 마트 부문에서 모두 국내 업체 중 가장 많은 점포를 운영하고 있는 수치이며, 롯데쇼핑은 향후 이러 한 해외 진출에 더욱 박차를 가하겠다는 의지 를 보이고 있다.

롯데쇼핑의 이러한 활발한 해외 진출은 기본 적으로 글로벌 유통업체로의 도약을 노리는 목 표와 그 궤를 함께한다. 예를 들어 롯데쇼핑의 백화점 부문은 2007년 세계 12위에서 2013년에 10 위권 내로 진입하고 2018년에는 '최고 수준의 백화점(Global Top Player)'로서의 위상을 확립 하겠다는 비전을 내세우고 있다(Deloitte Report 2007, PlanetRetail 2007). 하지만, 국내 유통시 장의 성장세가 과거와 같지 않다는 것이 문제 다. 국내 유통 산업이 더 이상 빠른 외형성장을 보장하기 어려운 상황에 처해있다. 기본적으로 유통업체의 수익은 고객 수와 객단가의 곱으로 이루어져있다. 순수한 무점포 판매 업체가 아닌 이상, 고객 수는 매장 수의 영향을 받을 수밖에 없다. 지속적인 성장이 가능하기 위해서는 객단 가를 늘리기 위한 노력과 동시에 미개척 시장 으로의 사업 확장이 필요했다.

\subsection{2 해외 목표 시장 선정}

롯데쇼핑이 해외진출을 본격적으로 모색하기 시작하면서, 어떤 시장으로 진출해야할 것인지 에 대한 고민이 필요하게 되었다. 시장의 크기 와 잠재력, 그리고 시장 내의 경쟁 상황 등을 면밀히 분석한 결과, 롯데쇼핑은 'VRIC's' 시장 을 목표 시장으로 선정했다. VRIC's는 4대 신흥 
〈표 2〉 VRIC'S 국가의 시장 성장률과 매력도(2009년 기준, CAGR은 2004 2009, 내부자료)

\begin{tabular}{|c|c|c|c|c|c|}
\hline & GDP성장률 & CAGR & $\begin{array}{c}\text { 인구수 } \\
\text { (백만명) }\end{array}$ & $\begin{array}{c}\text { 시장크기 } \\
\text { (USD mil) }\end{array}$ & CAGR \\
\hline Vietnam & $3.3 \%$ & $6.9 \%$ & 88 & 39,146 & $13.7 \%$ \\
\hline Russia & $6.5 \%$ & $4.3 \%$ & 141 & 356,520 & $13.4 \%$ \\
\hline India & $5.4 \%$ & $8.2 \%$ & 1,208 & 472,326 & $10.0 \%$ \\
\hline China & $7.5 \%$ & $10.3 \%$ & 1,334 & $1,210,122$ & $15.5 \%$ \\
\hline Indonesia & $2.5 \%$ & $5.2 \%$ & 231 & 190,444 & $11.0 \%$ \\
\hline Global & $1.4 \%$ & $3.3 \%$ & 6,799 & $12,416,899$ & $6.4 \%$ \\
\hline
\end{tabular}

성장국을 의미하는 BRIC's에서 브라질(Brazil) 의 ' $\mathrm{B}$ '를 베트남(Vietnam)의 ' $\mathrm{V}$ '로 바꾸고, 기 존의 인도(India)를 의미하던 'I'에서 인도네시 아(Indonesia)를 추가한 개념이다. 즉, 롯데쇼핑 은 베트남, 러시아, 인도네시아, 중국을 첫 진출 목표 시장으로 삼은 것이다.

이는 시장 자체의 매력성도 있었지만, 해당 시장에 진출했을 때 국내에서 쌓아온 롯데쇼핑 의 기술과 노하우를 충분히 적용할 수 있는 시 장인지 여부도 중요한 판단 기준이 되었다. 그 리고 이들 국가들은 성공적인 진출이 이루어졌 을 때, 한국 제품들의 해당 시장으로의 진출이 원활해질 가능성이 있고, 더불어 아시아 주요 거 점을 확보함으로써 글로벌 소싱(Global Sourcing) 이 가능하다는 장점이 있다. 특히 마트부문의 경우, 2010년 안으로 롯데마트 글로벌 조달 센 터(Lotte Mart Global Procurement Center)를 수립하여 물류 효율화 및 상품 경쟁력을 추구 하겠다는 계획을 가지고 있다.

롯데쇼핑의 그 동안의 해외진출 사항을 살펴 보면 〈그림 2〉와 같다. 2007년 9월 롯데쇼핑의 해외 첫 점포인 러시아 모스크바점을 개점하기 전부터 롯데쇼핑은 예견경쟁과 뉴파워 준비경
쟁을 통해 해외진출 전략에 박차를 가하였다 (김정구, 2005). 2005년 12월에는 베트남 기업 과 합작을 체결하고 2006년 8월에는 중국과 $\mathrm{MOU}$ 를 체결하고 합작법인을 설립했으며 국내 와 런던에 동시 상장을 하며 글로벌 진출을 위 한 철저한 준비를 하였다. 롯데백화점은 중국 북경점을 아시아 시장의 교두보로 삼아 다점포 네트워크 구축에 힘쓰고 있다. 또한 롯데마트는 중국과 인도네시아에서 타임즈와 마크로를 인 수하는 등 세계적인 유통업체로 거듭나기 위한 해외진출 노력을 하고 있다.

\section{2 롯데백화점 해외진출 전략}

\subsection{1 진출현황 및 전략}

2010년 3월말 기준으로, 롯데백화점의 해외 점포는 러시아 모스크바와 중국 북경에 각 1 개 씩, 총 2 개의 점포가 운영되고 있다. 기본적으 로 롯데백화점의 해외 점포들은 단순한 의류 위주가 아니라 식품, 잡화, 의류, 가전 등 모든 유통 라인을 갖춘 모스크바 최초의 풀 라인 (Full-line) 백화점의 형태를 띠고 있다. 그리고 
〈그림 2〉 롯데쇼핑 주요 해외진출 사항

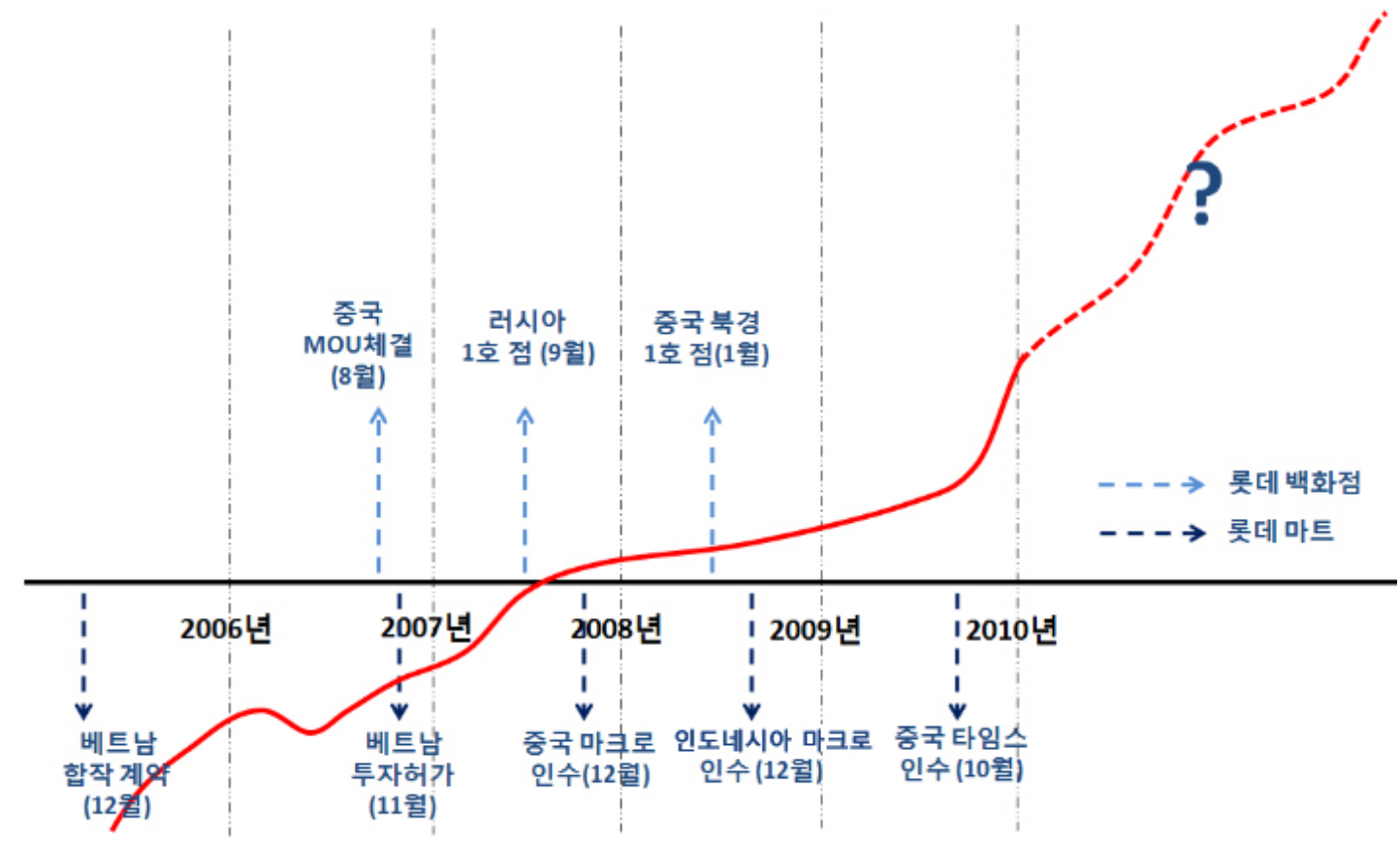

매장 별로 별도로 운영되는 숍인숍(shop in shop) 형태가 아니라, 오픈 스타일(open-style)의 '한 국형 백화점'으로 인테리어를 구성했다.

운영 방식에 있어서도 초기 브랜드 인지도 강 화를 위한 공격적인 마케팅을 실시하고 있으며, 국내에서 운영 중인 다양한 고객관리 프로그램 과 $\mathrm{CRM}$ 시스템을 적극 활용하여 신규고객을 창출하고 기존고객의 충성도를 제고한다는 방 침을 세우고 있다. 더불어 인력 구성에 있어서 도 운영에 필요한 최소한의 인원을 제외하고는 모두 현지인을 채용하고, 보고서나 회의 등도 현지어를 통해 이루어지는 현지화 정책을 펼치 고 있다.

(1) 모스크바 롯데플라자

롯데백화점은 2007년 9월 2일, 해외점포로는
처음으로 러시아 모스크바(Moscow)에 '롯데플 라자(LOTTE Plaza)'를 개점했다. 이는 국내 백화점 업계의 최초 해외진출로 기록되었다. 롯 데 플라자는 명품, 미들 클래스 브랜드들과 더 불어 한국브랜드를 적절히 조화시켜서 글로벌 백화점의 이미지를 강조했다. 더불어 현지 컨설 팅을 토대로 현지 문화와 정서를 고려한 매장 구성, 서비스, 편의 시설 등을 구축해 현지 유 통업체들과의 차별화를 추구했다. 점포 구성 이 외에도 고객관계관리(CRM) 측면에서도 기존 에 볼 수 없었던 전략을 내세워 차별화했다. 철 저한 분석을 토대로 고객의 취향을 정확히 파 악하는 밀착형 마케팅을 벌임과 동시에, VIP고 객들을 대상으로 한 특별한 서비스를 선보여 우량 고객들의 마음을 사로잡겠다는 전략을 시 행했다. 
하지만 개점행사에서 모스크바 시장을 비롯한 30 여 개의 주요 언론사가 참석하여 롯데백화점 의 러시아 진출에 큰 관심을 보였던 반면에, 아 직 롯데플라자가 성공을 거두었다고는 말하기 힘든 실정이다. 롯데플라자의 현대적인 컨셉은 모스크바 시민들이 생각하는 백화점의 특징과 는 차이점이 있었고, 아직까지 이러한 컨셉의 장점이 잘 받아들여지지 않고 있기 때문이다. 특히나 세분화가 잘 되어있는 러시아 유통업체 들에 비해 저렴한 제품에서 고급 제품까지 모 두 취급하는 롯데플라자의 형태는 명확한 컨셉 을 잡기가 힘들었다. 더군다나 타 백화점들이 가진 고풍스러운 외관에 비해 현대적인 롯데플 라자의 외관은 소비자들에게 고급스러운 느낌 을 주기에 부족했다. 그러나 최근 매출 신장세 가 크게 개선되고 있어 현지 적응을 마치면 시 간차를 두고 성장할 것으로 예상된다.

(2) 북경 인타임 롯데

롯데백화점은 2006년 8월, 중국 진출을 위해 조직을 개편하고, 10 월에 인타이(銀泰)그룹과 전략적 양해각서(MOU)를 체결한 이후, 2008년 8 월 1일에 중국 북경(Beijing)에 해외 2호점인 인타임 롯데(Intime Lotte)를 개장하여 운영 중 이다. 매장 구성에서는 한국 브랜드들을 입점 시키고, 풀 라인을 갖췄다는 점 등에서 모스크 바점과 큰 차이를 보이고 있지는 않다.

아직 성공했다라고 진단을 내리기엔 이르지 만, 현지에서의 평가는 대체적으로 긍정적이다. 대개 2 3년이 걸려서 매출이 정상궤도에 진입 하는 것이 중국 백화점 업계의 특징인데 반해, 롯데백화점은 채 2 년이 안 걸린 것으로 평가받 고 있다. 그리고 지속적인 고객관리를 통해 관
광객 위주가 아닌 현지 상류층의 비중이 늘어 나면서 고가품 판매가 늘어나고 있고, 약점으로 지적되었던 명품브랜드들이 입점하기 시작했다. 이를 적극 활용하기 위해 인타임 롯데 건물에 는 MVG(Most Valuable Guest) 라운지가 명 품관인 1 층과 가까운 2 층에 위치하고 있다. 이 러한 변화를 통해 인타임 롯데는 당초 중고급 백화점의 이미지에서 고급 이미지로 변해가고 있다.

\section{(3) 향후진출 전망}

현재 롯데백화점이 러시아, 중국 시장에서 완 전한 성공을 이루었다고는 말하기 어렵다. 하지 만 해외 시장 개척에 대한 롯데백화점의 의지 는 꺾이지 않을 것으로 보인다. 2010년 4월, 롯 데백화점은 2018년까지 VRIC's 국가를 중심으 로 31 개 백화점을 추가로 개점하겠다는 계획을 밝혔다. 이에 따라, 해외사업본부를 신설하는 조직 개편도 실시했다. 지난 3 년간의 시장조사 단계를 넘어서 본격적인 시장개척 및 진출 단 계에 들어선 것이다.

구체적인 진출 계획을 살펴보면, 먼저 중국에 서 2011년에 합작의 형태가 아닌 단독 진출의 형태로 텐진에 출점을 예정 중에 있고, 상하이, 광저우, 선양 등 주요 거점 도시를 중심으로 진 출 계획을 수립하고 있다. 러시아에도 모스크바에 추가 점포 또는 상트페테르부르크(St. Petersburg) 에 2호점을 개장한다는 계획을 가지고 있다. 초 기 성과에 대하여 고전 중이라고 평가받는 러 시아 시장이지만 롯데백화점측은 지금까지는 시 장조사 단계였고 본격적인 출점은 지금부터라 는 자신감을 내비치고 있다. 베트남의 경우에 도, 2008년 10월부터 호치민(Ho Chi Minh)시 
의 다이아몬드 백화점의 수탁 경영을 맡아온 노하우를 적극 이용하여 하노이에 첫 점포를 2013년에 개점할 계획을 세웠다.

\section{3 롯데마트 해외진출 전략}

\subsection{1 진출현황 및 전략}

롯데마트는 2010년 3월 말을 기준으로, 총 101 개의 점포를 해외에서 운영하고 있다. 이는 국 내 업체들 중에서 가장 많은 숫자(이마트, 24개 점포)이고, 국내에서 운영하고 있는 점포(84개) 보다도 많은 숫자이다(2010년 인수 GS마트 14 개 점포를 포함한 수치). 구체적으로는 중국 81 개 점포, 베트남 1 개, 인도네시아 19 개 점포를 운영하고 있다. 다소 고전 중에 있는 백화점 부 문과는 달리, 마트 부문의 해외 진출은 현재까 지는 상당히 성공적이라고 평가받고 있고, 그 진출 속도도 매우 빠르다. 롯데마트의 해외진출 의 특징은 인수의 비중이 높다는 점이다. 현재 운영 중인 점포 중에서 인수를 통해 확보된 점 포의 비율은 $80 \%$ (82개 점포)가 넘는다.

롯데마트의 해외점포 전략의 중요한 점은 아 시아 1 등 유통기업이라는 비전과 함께 한다. 비 록 유통공룡이라고 불리는 월마트(Wal-mart), 까르푸(Carrefour) 등의 글로벌 기업이 해외시 장에서 성장을 거두고 있으나 특히, 롯데마트는 신흥 아시아 4 개 국가의 진출을 통해 아시아 시장을 선점하려는 모습을 보이고 있다.

이를 위해 롯데마트는 5 가지 핵심 전략을 제시 하고 있다. 첫째, 고객 통찰력(Customer Insight) 이다. 이는 고객이 지니고 있는 필요에 대한 올 바른 이해를 지니고 사업 개선을 시행하는 것
으로써 고객만족의 극대화를 목표로 하는 것이 다. 둘째, 적절한 인력의 배치(Right People)이 다. 해외 시장 진출은 다양한 문화, 인종, 기호 등으로 인해 어려움을 겪는 것이 사실이다. 따 라서 현지 구성원과 함께 비전 공유, 동기부여, 교육 훈련 등을 통해 글로벌 리더를 성장시킴 과 동시에 윤리경영을 시행하는 목적을 지니고 있다. 셋째, 확장 가속화(Speedy Expansion) 전략이다. 유통 산업은 지역 비즈니스의 성격 을 지니고 있기 때문에 공격적인 M\&A를 통 해 현지 상인들의 반발을 최소화시키기 위한 전략을 활용하고 있다. 넷째, 맞춤화된 머천다 이징(Customized Merchandizing)이다. 고객의 요구와 $\mathrm{CRM}$ 데이터를 활용한 머천다이징과 공급자와의 협력을 통해 “원스톱 쇼핑을 통한 즐 거움을 추구”라는 매장 컨셉의 목표를 실현하 고 있다. 마지막으로 효율적인 운영(Optimized Operation)이다. 각 국가의 적합한 운영방식과 롯데마트 글로벌 IT에 기반을 둔 시스템을 활 용하여 효율적인 운영 시행하고 있다.

롯데마트는 철저한 '한국식 할인점’을 출점시 키고 있는 이마트의 해외 진출과 다른 방식의 전략을 활용하고 있다. 이는 글로벌 기업과의 경쟁 환경 속에서 단기간 내 현지에서 자리를 잡고 롯데마트 고유의 특성으로 차츰 변화시킴 으로써 글로벌 유통기업으로의 성장 목표를 이 루어 나가는 모습을 보여주고 있다.

\section{(1) 중국 롯데마트}

중국의 13 억 넘는 인구를 고려했을 때 향후 중국 시장의 대형마트는 최고 1 만개 이상 대 형마트가 늘어날 것이라는 예상이 있는 가운 데 현재 중국 대형마트 시장에는 이미 월마트 
(Wal-mart), 까르푸(Carrefour) 등의 글로벌 업 체들이 다수 진출해있어 경쟁은 더욱 심화되고 있다. 롯데마트 역시 중국시장 진출에 박차를 가하고 있다. 2007년 12월 네덜란드계 대형마트 체인인 마크로(Makro)의 8개 점포(북경 6개, 텐진 2개)를 인수하면서, 해외시장으로는 처음 으로 중국 시장에 진출했다. 이후, 2008년 6월 망경점, 사도구점, 숭문문점을 개장한 데 이어, 2009년 10월에는 중국 현지 대형마트 체인인 타임스(TIMES)를 인수하여 중국 시장 내에서 중요한 전략적인 거점을 마련했다. 인수 당시, 타임스는 화동지역을 중심으로 총 65개(현재 70개 점포)의 점포를 운영 중이며, 강소성에 약 $33000 \mathrm{~m}^{2}$ 규모의 물류센터도 보유하고 있다.

(2) 인도네시아 롯데마트

2006년 롯데쇼핑의 주요 해외시장 목표는 'VRIC's'였다. 하지만 인도는 개방이 더디고 진 입 장벽이 높아 그 대신 성장이 빠르고 잠재력 이 큰 인도네시아로 선진출한다는 전략으로 수 정하게 되었다. 이에 따라, 롯데마트는 2008년 10 월 7 일, 중국 진출의 경우와 마찬가지로, 마 크로를 'PT 마크로 인도네시아(PT Makro Indonesia)'로부터 인수하여 인도네시아에 진출 했다. 마크로는 인수 당시에 자바섬에 12 개, 수 마트라섬에 3 개, 칼리만탄섬에 2개, 슬라웨시섬 에 1 개 등 총 19 개 점포를 운영 중이다. 현재 마크로는 도매형 점포로 운영 중이며 이 중 일 부 점포는 소매형 대형마트로 바꾸는 한편 2010년 3 4개 소매형 점포를 새로 출점하기로 하였다. 이와 함께 도매형 점포는 '롯데마트 홀 세일(LOTTEMART Wholesales)'로, 소매형 점 포는 '롯데마트(LOTTEMART)'로 상호를 변
경하는 작업도 진행 중이다. 또한 인도네시아 사업 강화를 위해 인도에 있던 공급업체(상품 발굴-조달) 사무소도 자카르타로 옮기는 계획 을 가지고 있다.

(3) 베트남 롯데마트

2005년 12월, 베트남 기업(INTIMEX) 과 합작 계약을 체결한 후, 2006년 11월에 롯데마트는 국내 유통업체로는 처음으로 베트남 소매업 투자 허가를 받아내고, $80 \%$ 지분을 가지는 합작법인 인 '롯데 베트남 쇼핑(Lotte Vietnam Shopping)' 을 설립했다. 이후 2008년 12월에 롯데마트 베 트남 1호점을 남사이공에 개점했다. 아직까지 세계적인 마트업체들이 베트남 시장에 진출해 있지 않은 상태에서 경제성장률과 소비 수준이 지속적으로 상승하면서, 현대적 유통시설에 대 한 소비자들의 욕구가 큰 점이 롯데마트에게 기회로 작용하고 있다. 특히 1 호점이 개장한 남 사이공 지역은 비교적 소득 수준이 높고 신도 시 개발 지역과 가까운 상권이라서 진출 기반 을 닦기에 제격이다. 특히, 남사이공점은 직접 부지를 확보하고 매장을 꾸민 진정한 의미의 해외 첫 점포라는 점에서 의의가 깊다.

베트남 롯데마트는 현지화 전략과 한국 특화 전략을 함께 구사하고 있다. 롯데마트는 더운 기후를 고려해 신선식품을 가장 나중에 구입할 수 있도록 신선식품 매장을 안쪽에 배치하고, 주 교통수단인 오토바이를 고려하여 오토바이 용품 전문 코너를 운영하고 있다. 또한 인삼, 김치, 라면, 소주 등 베트남에서 인기가 많은 300 여 개의 한국 상품을 판매하는 특별 매장도 배치했다. 더불어 국내에서 운영하고 있는 마일 리지 제도, 신선식품 보증제도, 최저가 보상제 
도 등의 고객관리 제도를 통해 차별화된 서비 스를 선보였다. 그리고 롯데마트는 단순한 쇼핑 시설이 아니라 문화센터와 롯데시네마, 패밀리 레스토랑, 볼링장, 당구장 등 대규모 편의시설 들과 문화시설을 갖추고 있는 최고의 쇼핑센터 로 자리매김했다.

\subsection{2 향후 진출 전망}

롯데마트는 중국 시장에서 현재 점포가 집중 되어 있는 서북부지역에서 벗어나 중부 지역과 중남부 지역으로 남동방향으로 진출을 확대해 3 년 안에 중국 대형마트 시장에서 10 위권 안에 진입하겠다는 목표를 가지고 있다. 인도네시아 에서는 국내 유통업체 최초로 진출해 이렇다 할 역할모델이 없는 만큼 현지 고객 특성을 반 영한 철저한 현지화와 현지 업체와의 차별화를 병행해 추진할 계획이다. 베트남 역시 호치민, 하노이 등 주요 거점 지역을 중심으로 10년 내 30 여 개 점포를 추가로 오픈할 계획이다.

\section{4 해외진출의 의의와 향후 과제}

롯데쇼핑은 다가올 국내 유통시장의 포화에 따라 지속적인 성장이 불가능해질 것으로 예상 하고 해외진출을 적극적으로 모색했고, VRIC'S 시장으로의 첫 발걸음을 내딛은 상태이다. 롯데 쇼핑은 현재 $97 \%, 3 \%$ 인 국내시장과 해외시장 의 매출비율을 2018 년까지 $70 \%, 30 \%$ 까지 늘릴 계획 하에 해외시장에 많은 비중을 두고 내부 적 역량을 집중하고 있는 상황이다. 본격적인 진출이 이루어졌던 2007년 이후, 3년이 채 안 되는 기간을 두고 성공과 실패의 판단을 내리
기에는 아직 이르다. 하지만 분명한 것은, 롯데 쇼핑의 해외진출이 기업 내·외부적으로 의의를 지닌다는 점이다.

먼저, 글로벌 유통기업으로의 성장을 도모하 고 있는 롯데쇼핑에게 VRIC's 시장은 새로운 동력이 될 수 있다. 특히 중국과 인도네시아 등 에 성공적으로 진출할 경우, 물류 효율화와 상 품 다양화를 추구할 수 있어 향후 국내 및 아 시아 시장에서의 경쟁력을 높일 수 있다. 특히, 앞서 언급한 글로벌 소싱이 가시권에 접어들면 서 중국-베트남-인도네시아-한국을 잇는 소싱 네트워크(sourcing network)를 구축하게 된다 면 국내는 물론 아시아 3 개국 간에도 시너지를 발휘할 수 있는 조건이 형성된다. 롯데마트측은 2012년에 이 글로벌 소싱 규모가 3500억원 규 모로 성장할 것으로 전망하고 있다. 결국, 성장 에 한계가 있는 국내 시장만으로는 롯데쇼핑이 추구하는 글로벌 기업으로의 도약이 불가능하 기 때문에, 현재의 시행착오는 앞으로의 성장을 위한 거름이 되어 줄 것이다. 더불어 백화점과 마트 부문의 해외진출은 국내 업체들이 성공적 으로 해당 시장에 진출할 수 있는 기회를 마련 해준다. 특히나 자체적으로 해외 유통망을 개척 하기 힘든 중소기업들에게 롯데쇼핑은 이들을 소개해주는 든든한 지원군으로서의 역할을 할 수 있다.

하지만 이러한 해외진출의 의의가 현실화되기 위해서는 현재 맞닥뜨린 문제점을 해결해야 할 것이다. 가장 시급한 문제는 명확한 롯데쇼핑만 의 색깔을 찾는 것이다. 풀 라인 백화점과 한국 형 할인점의 컨셉은 분명히 그 강점을 가지고 있다. 하지만 러시아 롯데플라자의 경우처럼 해 당 시장 소비자들에게 그 매력이 충분히 전달 
되지 않고 있는 실정이다. 또한 마트 부문의 경 우, 기존 업체를 인수하여 급속하게 성장해 온 탓에 롯데마트만의 독특한 색깔을 드러내기가 아직은 힘든 상황이다. 따라서 공격적인 점포수 의 확장도 있어야겠지만, 그 이전에 롯데쇼핑만 의 색깔을 입히고 이를 소비자들에게 충분히 알려야할 필요가 있다. 제대로 된 핵심 우위를 갖추지 않은 상태에서의 무분별한 외형 성장은 오히려 독이 될 수 있음을 명심해야 할 것이다.

경험해보지 못한 시장으로의 확장은 반드시 시간을 필요로 한다. 현재의 상황만을 두고 안 주하거나 겁을 먹기보다는, 지속적으로 현지 소 비자들에 맞춰진 전략의 수행과 차별화된 우위 마련이 행해져야 롯데쇼핑의 해외진출이 '진출 을 위한 진출'이 아니라 '성장을 위한 진출'로서 의 의미를 갖게 될 것이다.

\section{IV. 인재개발을 위한 롯데쇼핑의 교육시스템}

롯데쇼핑은 기업이 성장할 수 있는 기반이 되 는 가장 중요한 요소가 능력 있고 성실한 인재 채용과 인재육성이라고 생각하고 있다(Levy and Weitz 2008). 롯데쇼핑의 인재교육은 1980년대 부터 시작되었다. 다양한 교육프로그램을 통하 여 내부 구성원들이 부단하게 자기계발을 할 수 있는 여건을 마련하려고 노력했다.

롯데백화점은 1988년 올림픽 공식 백화점으로 '베스트 롯데(Best Lotte)'를 달성하고 서비스 질을 최상으로 끌어올리기 위해 서비스 정신 함양, 자질향상 및 능력개발을 목표로 교육과정
을 운영하였다. 롯데쇼핑의 초기 교육은 업무 분야와 계층에 따라서 해외연수 및 국내교육을 실시하였다. 교육시스템은 워크숍, 현장체험 학 습 등 다양한 방법에 의하여 운영되었다. 예를 들어 서비스 교육에서 고객과 점원의 롤플레잉 (role playing) 방법 등을 활용하여 현장에서 바로 적용할 수 있는 방법들이 채택되었다.

\section{1 유통대학 설립 및 교육시스템 확대}

1994년에는 롯데쇼핑이 새로운 교육제도를 정 착시켰다. 유통대학을 설립하여 이수학점 제도 와 자기계발 과정을 도입하는 방식을 채택하는 획기적인 제도를 시작한 것이다. 유통대학은 전 문 인력을 양성하여 기업 경쟁력을 향상하기 위 한 목적으로 운영되었다. 이수학점 제도는 내부 구성원들이 적극적인 능력 개발에 노력을 기울 이는 계기가 되어 자발적인 교육 참여가 자연스 레 이루어졌다. 한편, 기업의 관리과정 향상에도 기여하였다. 유통대학 성과를 인사시스템과 연 계시켜 개인별 경력관리가 용이하게 되었다.

유통대학에는 유통학, 머천다이징, 판매촉진, 판매관리, 매장연출 등의 실무 과목과 외국어 습득 과목으로 구성되었으며 일반직 3,4 급 사 원이상을 대상으로 3 학기 1 년 동안 운영되는 과정이다(롯데쇼핑 2009). 이 수업에서는 롯데 쇼핑이 직면한 문제에 대한 이론 학습 및 심층 토의, 아이디어 제안, 문제 해결 등 현장에서 일상적으로 나타나는 과제를 통하여 실무적인 능력 배양을 위한 워크솝 형식으로 진행되었다.

롯데쇼핑의 교육과정은 일반적인 교육을 넘어 사회봉사정신을 기르는 동시에 전문성을 강조 하는 등 다양한 유형으로 발전을 이루었다. 
1995년에는 신입사원 기본과정에서 사회봉사활 동을 추가하여 홀트아동복지회에서 봉사활동을 실시하고, 1998년 유통대학의 핵심전문 인력양 성과정을 백화점 부문과 할인점 부문으로 이원 화하여 전문성을 강화하기도 하였다.

이 후 유통대학 시스템을 더욱 확대하여 직급 별 교육제도를 정착시켰다. 유통대학을 마친 후 과장급이 되면 매니저-바이어 전문가 과정을 실시하고 차장부장급이 되면 유통 $\mathrm{MBA}$ 과정을 이수하도록 하였다. 임원급 점장이 되면 점장능 력향상교육 등을 추가하여 지속적인 교육 프로 그램을 운영하였다. 직급에 적합한 전문적인 지 식을 지속적으로 축적할 수 있는 분위기와 시스 템을 구축하는 것이 중요한 교육 목표였다. 예를 들어 유통 $\mathrm{MBA}$ 과정은 17 주 동안 진행되면서 마 케팅전략, 전략적 경영, $\mathrm{e}$-비즈니즈, 유통 및 물 류관리 등을 수강하여 실무에 필요한 전문적인 지식을 축적하도록 하였다(롯데쇼핑 2009).

교육제도와 함께 직무자격제도, 상사코칭시스 템 등을 활용하여 교육시스템을 보완하기도 하 였다. 이 외에도 여성인재 양성을 목적으로 2001 년부터 직무전환제도를 운영하여 근무의욕을 고취시키고 우수 인력의 관리자 등용의 기회를 만들었다. 또한, 여성 직원들의 학업욕구를 충 족시키고자 2년 전문학사 정규과정의 위탁사내 대학을 운영했다.

\section{2 경쟁사의 인재개발시스템}

\subsection{1 신세계}

신세계는 세계 초일류 유통기업(A world Renowned Retailer)의 기업 비전을 위해 4대 전략을 바탕
으로 경영정책을 세웠다. 신세계의 4 대 전략이 란 1) 다양한 형태의 신업태 발굴, 2) 글로벌화 (Globalization)에 맞는 핵심인재를 양성을 위한 교육, 3) 중국시장 진출과 글로벌 소싱 (Global Sourcing) 등 해외시장 확대, 4) 문화로 정착된 적극적인 윤리경영이다(http://about.shinsegae. com/company/COVisionV.asp). 신세계는 인재 육성을 4대 전략에 포함할 정도로 중시하고 있 으며 이를 실천하기 위하여 도덕성, 실천, 전문 성 등의 3 대 덕목을 강조하는 교육프로그램을 운영하고 있다.

직무별 전문성을 강조하기 위하여 바이어를 대상으로 선진 유통업체 견학 및 해외 파견교 육 등을 실시하고 있다. 미국 뉴욕의 패션기관 에서 패션 상품학, 패션 머천다이징, 최신 패션 트렌드 등을 연구한다. 한편, 일반직 사원에 대 해서 롯데쇼핑과 비슷하게 직급별 교육 시스템 을 구축하여 전문성 증진을 위한 교육 프로그 램을 운영하고 있다.

\subsection{2 현대백화점과 현대홈쇼핑}

현대백화점은 고객의 행복과 주주 및 구성원 의 감동을 최우선으로 하여 새로운 가치와 미 래 창조를 기업이념으로 삼고 있으며 현대백화 점의 인재상은 주도적 인재, 성과지향적 인재, 창의적 인재 등이다(http://www.ehyundai.com). 이러한 목적을 달성하기 위하여 미래지향적 유 통 전문 인력과, 서비스분야의 전문 인력을 양성 하는데 주력하고 있으며 숭의여자대학 산학협동 프로그램, 현대유통대학, 현대 유통대학원, 현대 백화점 서비스 아카데미 등을 운영하고 있다.

롯데쇼핑과 유사하게 교육과정이 계급별로 다 
르게 구성되어 있다. 여성 직원을 중심으로 숭 의여자대학 프로그램, 초급, 중급자 대상 현대 유통대학, 임원이 되기 위한 필수과정인 현대유 통대학원 등이 있다. 서비스 아카데미는 전문강 사 및 서비스 리더를 양성하기 위한 과정으로 사원에서 부장까지 수강하고 시험 후 자격증을 수여한다.

\subsubsection{GS홈쇼핑}

$\mathrm{GS}$ 홈쇼핑의 인재육성 프로그램은 4 가지 요소 에 초점을 맞추고 있다. 1) 글로벌(Global)마케 팅 역량 강화, 2) 커뮤니케이션 경쟁력 강화, 3) 상품 경쟁력 강화, 4) 서비스 강화를 통한 철 저한 $1: 1$ 고객 서비스 등이다(http://company. gsshop.com/recruit/ability.jsp). 롯데쇼핑과 유 사하게 직급별 과정을 운영하고 있으며 모든 과정에 윤리경영 과목을 운영하고 협력업체와 공동발전을 찾을 수 있는 능력을 갖추도록 하 고 있다. 또한, 세계적인 홈쇼핑 기업으로의 비 전에 맞게 외국어 교육에 집중 투자하고 있다.

\section{3 롯데쇼핑의 특화된 교육프로그램}

롯데쇼핑뿐만 아니라 경쟁기업인 신세계, 현 대백화점 등도 인재육성을 위한 교육시스템 개 발 및 운영에 많은 투자를 수행하고 있다. 롯데 쇼핑은 한걸음 앞선 특화된 교육 프로그램 개 발의 필요성을 크게 느끼고 있었다. 이러한 필 요에 의하여 개발된 대표적인 교육 프로그램이 인문학과정과 한국사 시험이다. 경영기법에 대 한 전문성 향상 및 서비스 정신 함양 등 직접 적인 업무능력 향상이라는 목표를 넘어서 문화
적인 이해를 통한 고객서비스 차원 향상이라는 혁신적인 접근방법에서 출발한 프로그램들이다. 하지만, 한편으로는 지나치게 시류를 앞서가고 있다는 평을 받기도 한다. 과감한 도전이라고 할 수 있는 인문학과정 및 한국사시험 등의 향 후 성과가 주목된다고 할 수 있다.

\subsection{1 롯데쇼핑의 인문학과정}

2009년, 서울대AFP(Ad Fontes Program)-롯 데백화점 인문학 과정을 개설했다. 서울대학교 인문대학이 일반 민간 기업과 인문학 과정을 개설한 적은 처음 있는 일이다(서울경제, 2009. 06.09). 2009년 만들어진 서울대 AFP-롯데백화 점 인문학과정은 총 8 주 과정으로 2 차로 나눠 서 진행이 되었다. 매주 토요일 3 시간씩 두 차 례로 나눠 진행이 되었다. 오전 8시 30 분에 오 전교육, 오후 2시에 오후교육으로 구성되어있었 다. 20여명의 인문대학 교수가 문학 - 철학 - 예 술 - 역사의 분야에서 다양한 주제로 수업을 진 행했다. '예술과 도덕' '인도의 신화와 예술', '한 국문학과 한국인' 등의 강좌가 진행되었으며, 참여하는 직원들은 이철우 사장을 포함하여 롯 데백화점 본사 임원 및 1 급(차장)이상의 팀장 으로, 2009년 총 87명이 인문학과정을 수료했다 (경향신문, 2009.06.09). 롯데백화점은 인문학과 정을 통해서 다차원의 문화 백화점으로서 창의 력 높은 문화마케팅을 전개한다는 이미지를 구 축하고 이를 실천할 수 있을 것으로 기대하고 있다. 롯데백화점은 인문학과정을 통해서 감성 적인 리더십과 인문학적 소양을 양성하고 이를 배경으로 경영활동 전반에 활용한다는 목표를 가지고 있다. 
롯데쇼핑은 글로벌 기업이 되기 위한 첫걸음 은 올바른 역사관에 있다고 생각하고 있다. 이 철우 사장은 직원들의 가슴에 국가관을 심어주 고 싶었기 때문에 한국사 시험을 실시한다고 이야기 하였다. "이 나라, 이 민족이 얼마나 험 난한 시련을 이겨내며 여기까지 왔는지를 마치 자신의 일인 것처럼 생생하게 느끼는 것이 역 사 공부다. 역사공부를 통해 국가관이 뚜렷하게 형성된 직원이 많은 조직은 기업의 성과도 높 을 것이라 생각한다. 자신의 뿌리인 민족과 나 라를 아는 만큼 자신이 나아가야 할 큰 방향도 잘 세울 수 있다고 믿기 때문이다. ...(중략)... 글로벌 비즈니스 세계에서도 마찬가지다. 상대 를 알고 싶거든 나를 제대로 알아야 한다(이철 우 2009)."

글로벌 기업 도약이라는 목표를 달성하기 위 하여 롯데쇼핑은 2007년부터 승진 과목에 국사 를 포함시켰다. 백화점 직원이 차장, 과장으로 의 진급 대상자는 한국사시험에서 2 급을, 계장, 주임으로의 진급 대상자는 3 급 자격증을 따야 진급할 수 있다. 이 시험을 위해 여름휴가에 공 부하는데 시간을 보낸 직원들도 있고, 회사에서 국사 책을 펴놓고 공부하는 직원도 있다(중앙 일보. 2009.08.13). 롯데백화점 박대훈 인력개발 팀장은 “직원들이 한국사 공부를 통해서 올바 른 역사관과 국가관을 바탕으로 미래 지향적인 생각을 갖고 Global 인재로 나아갈 수 있는 안 목을 갖게 될 것으로 기대한다.”고 말했다(세계 일보, 2009.08.13).
김병도, 주영혁 (2006), 한국백화점 역사, 서울대 학교 출판부.

김정구(2005), 미래마케팅, 교보문고.

농협경제연구소 (2008), 2009 국내 소매시장 전 망, 12월.

롯데쇼핑(2009), 롯데쇼핑 30년사(1979-2009). 이철우 (2009), 열린 가슴으로 소통하라, 더난출판. Deloitte (2010), "Global Powers of Retailing, Emerging from the Downturn," Store, January. Levy, Michael and Barton Weitz (2008), Retailing Management, 7th edition, McGraw Hill.

인터넷 및 신문 자료

경향신문(2009.06.09)

서울경제 (2009.06.09)

세계일보(2009.08.13)

http://about.shinsegae.com/company/COVisionV. asp

http://company.gsshop.com/recruit/ability.jsp http://dart.fss.or.kr

http://www.ehyundai.com

http://www.lotte.com

http://www.lotteshopping.com/lotte/about/ceo /ceo.jsp 


\title{
Lotte Shopping's Marketing Strategy for Achieving the Goal of Becoming a Global Leader*
}

\author{
Lee, Jinyong** \\ Kim, Chung Koo*** \\ Joo, Young-Hyuck ${ }^{* * * *}$
}

\begin{abstract}
Lotte Shopping Co. started its business from Lotte Department Store. From the beginning, Lotte Shopping Co. opened the largest department store and, since then, has expanded its business size through the processes of active developments of its own stores and merges and acquisitions of other companies. Currently, it operates a variety of retail shops such as department stores, discount stores, movies theaters, shopping malls, and supermarkets along with a TV home-shopping station and an online shopping mall.

Lotte group, a business conglomerate Lotte Shopping belongs to, has an objective of becoming TOP 10 business group in Asia by 2018. Lotte group declared its vision statements in 2009 and has spent its effort to accomplish the goal. Lotte Shopping is implementing the group-level growth strategy through merges and acquisitions and diverse marketing programs.

We will briefly investigate the current situation of Lotte Shopping and will then analyze its 1) entertainment shopping center and multi-channel strategy, 2) global market entry, and 3) education system.
\end{abstract}

Key words: Lotte Shopping, Lotte Department Store, Lotte Mart, entertainment shopping center, multi-channel strategy, global market entry, education system

\footnotetext{
* We thank Mr. Dae-Hoon Park and Dr. Insoo Baek of Lotte Shopping Co. for help with collecting some of data.

** Professor, College of Business Administration, Chung-Ang University

*** Professor, School of Business, Sungkyunkwan University

***** Associate Professor, School of Business Administration, Hansung University
} 